\title{
Using plant bioactive materials to control gastrointestinal tract helminths in livestock ${ }^{\text {is }}$
}

\author{
C.A. Sandoval-Castro ${ }^{\mathrm{a}, *}$, J.F.J. Torres-Acosta ${ }^{\mathrm{a}}$, H. Hoste ${ }^{\mathrm{b}, \mathrm{c}}$, A.Z.M. Salem ${ }^{\text {d,e }}$, J.I. Chan-Pérez ${ }^{\mathrm{a}}$ \\ a Facultad de Medicina Veterinaria y Zootecnia (CCBA), Universidad Autónoma de Yucatán, Km 15.5 Carretera Mérida-Xmatkuil, Mérida, Yucatán, Mexico \\ b INRA UMR 1225 Interactions Hôte Agents Pathogènes, 23 Chemin des Capelles, F31076 Toulouse, France \\ c Université de Toulouse, ENVT, UMR 1225, 31076 Toulouse, France \\ d Facultad de Medicina Veterinaria y Zootecnia, Universidad Autónoma del Estado de México, Toluca, Edo de México, Mexico \\ e Faculty of Agriculture (El-Shatby), Alexandria University, Egypt
}

\section{A R T I C L E I N F O}

\section{Keywords:}

Nutraceuticals

Phytotherapy

Helminth control

Farm animals

\begin{abstract}
A B S T R A C T
Use of plants containing bioactive compounds to control of helminths in the gastrointestinal tract, either as phytotherapeutic or nutraceutical options, has been a growing research area in recent years. We discuss strategies to identify viable candidate compounds with in vitro and in vivo anthelmintic properties. We also discuss factors which may influence in vitro and in vivo results, and difficulties of translating in vitro results to in vivo conditions are considered using experiences with small ruminants, as most published research on phytotherapeutic or nutraceutical materials has been in sheep and goats and has been reviewed recently. Therefore, we summarize results of various plant bioactive materials against helminth parasites in the gastrointestinal tract of cattle, deer, rabbits, pigs and poultry, and conclude that many plant materials have resulted in promising results in many farm animal species besides sheep and goats. These bioactive materials may be used as a part of sustainable helminth control strategies.
\end{abstract}

(C) 2012 Published by Elsevier B.V.

\section{Introduction}

The possibility of using plant bioactive compounds to control helminth parasites in the gastrointestinal tract, either as phytotherapeutic or nutraceutical options, has been a growing research area. There have been several review papers dealing with positive and negative effects of these compounds on animal physiology, performance and health (Hoste et al., 2005; Mueller-Harvey, 2006; Rochfort et al., 2008). Also, the anthelmintic (AH) effect of one class of bioactive compound (i.e., tannins), contained in many plants, against gastrointestinal nematodes (GIN) of small ruminants (i.e., sheep and goats) was recently reviewed (Hoste et al., 2012), including all available information of direct and indirect effects of AH against GIN. Hoste et al. (2008) provided a definition for phytotherapeutic and nutraceutical activity, as well as descriptions of several methodologies in an attempt to suggest guidelines for investigating possible AH effects of bioactive plants against GIN.

Abbreviations: AH, anthelmintic; AMIA, adult motility inhibition assay; CT, condensed tannins; EHA, egg hatch assay; GIN, gastrointestinal nematodes; LDA, larval development assay; LEIA, larval exsheathment inhibition assay; LFIA, larval feeding inhibition assay; LMIA, larval migration inhibition assay; PEG, polyethylene glycol; PSM, plant secondary metabolites; PVPP, polyvinylpolypyrrolidone; SL, sesquiterpene lactones.

is This paper is part of the special issue entitled: Plant Bioactive Compounds in Ruminant Agriculture - Impacts and Opportunities, Guest Edited by A.Z.M Salem and S. López, and Editor for Animal Feed Science and Technology, P.H. Robinson.

* Corresponding authors. Tel.: +52 999942 3200; fax: +52 9999423205.

E-mail addresses: ccastro@uady.mx (C.A. Sandoval-Castro), tacosta@uady.mx (J.F.J. Torres-Acosta), h.hoste@envt.fr (H. Hoste), asalem70@yahoo.com (A.Z.M. Salem), icp_1983@hotmail.com (J.I. Chan-Pérez). 
Other papers have discussed practical methods to use tannin containing materials against GIN of small ruminants, while considering practicalities in commercial production systems (Alonso-Díaz et al., 2010a; Torres-Acosta et al., 2012). However, less effort has been given to gathering information in relation to livestock species other than sheep and goats. Furthermore, very limited information is available on other types of plant bioactive compounds, or on the effects of those compounds against other types of helminths.

This review discusses some aspects which need to be considered when investigating in vitro and in vivo AH effects of phytotherapeutic or nutraceutical materials, and also presents a brief description of available results against helminths of cattle, deer, rabbits, pigs and poultry.

\section{Choosing the right candidates to evaluate for anthelmintic activity}

Many researchers have used ethnoveterinary information to choose possible plant candidates which could be tested as AH against internal parasites of humans and animals (Waller et al., 2001; Githiori et al., 2005, 2006). Another important source of information is direct use of questionnaires and interviews with key groups such as traditional healers (Sudarsanam et al., 1995; Ali, 1999; Matin et al., 2001) or farmers with practical experience (Smidt and Brimer, 2005). Many projects use these sources of information when trying to obtain valid information on plants which people recommend in the case of problems of the gastrointestinal tract, both in humans and farm animals. However, some may start by looking for antiparasitic effect of plants which are helpful for the stomach or to control diarrhea. These clinical signs could be related to different gastrointestinal ailments and not necessarily parasitic helminths. That parasites are hidden in the gastrointestinal tract complicates information gathering on which materials may affect those parasites. It is also important to consider that a medicinal remedy which may work in humans may not be useful in other animal species, such as ruminants.

Some research groups choose to follow the promising path of studying plants with bioactive components, either as phytotherapeutics or nutraceuticals, which have been shown to have a high level of anti-parasitic activity against the parasite of interest. This option could be followed for those parasites with similar life cycles in other hosts. A good example is the study of plants containing large amounts of cysteine proteinases, which are proteolytic enzymes in plants such as Ficus spp, Carica papaya, Ananas comosus and Actinidia chinensis (Stepek et al., 2004). Other examples are tannin containing plants which have known AH activity against GIN of ruminants, particularly sheep and goats (Hoste et al., 2012).

Irrespective of the methodology used to choose which materials are selected to search for an AH effect, those materials may be used as phytotherapy and/or nutraceuticals. A phytotherapy is based on a plant, or mixture of plants, used in a similar way as a synthetic AH drug, being to cure within a short term of use and is usually administered per animal (Hoste et al., 2008). In contrast, a nutraceutical is a feed used long term for health improvement and/or maintenance, and depends on voluntary intake by the animals (e.g., tannin containing forage or browse; Andlauer and Furst, 2002).

\section{How to prove that a plant material has in vitro anthelmintic activity?}

Some recent papers reviewed various in vitro tests to investigate antiparasitic activity against different stages of GIN, being egg hatch assay (EHA), larval feeding inhibition assay (LFIA), larval exsheathment inhibition assay (LEIA), larvae migration inhibition assay (LMIA), larval development assay (LDA) and adult motility inhibition assay (AMIA) (Hoste et al., 2008; Jackson and Hoste, 2010). The majority of in vitro research has been against small ruminant GIN. However we found little in vitro research with helminth parasites in other host species.

Even with the techniques already validated for a given parasitic species (i.e., GIN of ruminants) the protocols must be adjusted for local laboratory conditions, such as the type of water and $\mathrm{pH}$, temperature of the laboratory and strain of parasite studied, as it has been suggested for in vitro tests used to test AH efficacy (Coles et al., 2006). Also, the material tested might not be applicable to all tests.

\section{How to prove that a plant material has in vivo anthelmintic activity?}

The in vitro AH evidence obtained with a plant material against a stage of the life of a parasite is not sufficient to suggest direct AH effect in naturally infected animals. Thus, in vivo evidence is needed and the parameters to claim AH efficacy in a nutraceutical option cannot be those used for a product intended as an AH drug, such as those reported by Wood et al. (1995) for ruminants. In addition, the nutraceuticals do not need the same legal requirements and they can be commonly used as "every day" feed. However, it is important to consider aspects such as:

\subsection{Biological relevance of an in vitro technique}

In vitro tests used to screen materials for their AH effect might not have biological relevance for the parasites of interest in the target host. For instance, a reduction of egg hatchability of GIN in the presence of an extract is a valuable feature if the aim is to reduce pasture infectivity. However, that same material might have no effect against the worm burdens inside the host. Furthermore, when a given plant extract is screened with in vitro techniques, the results could show an AH effect when measured with one technique and a limited AH effect when measured with another (Alonso-Díaz et al., 2011). 


\subsection{What dose level is needed to achieve an in vivo AH effect?}

In vitro tests are designed to evaluate different concentrations of a plant extract against a life stage of a parasite. The level of extract showing an $\mathrm{AH}$ effect will need to be translated to in vivo situations when it is meant to be used as a phytotherapeutic. However when the plant is meant to be used as nutraceutical, the problem of dosage will depend mainly on the level of intake by the target animal species. With the latter approach, the animal is fed the plant material of interest ad libitum. The AH effect is then measured by comparing the treated infected group with a non-treated infected group. If the plant cannot give an AH effect when used ad libitum, then a lower level of intake may not produce a useful effect. In cases where an extract is used, the situation of dosage becomes more complicated. Translation of an in vitro concentration to the dose level needed in the digestive tract will require knowledge of the quantity of digesta in the gastrointestinal tract and the possible alteration and/or degradation of the extract due to digestion. How much of the active material will reach the target organ is unknown. This question is especially difficult in ruminants. If they are dosed with the plant extract, it is difficult to estimate how much will be needed to account for the size of the reticulum-rumen before it reaches the target organs (i.e., abomasum, small intestine, large intestine). Some of these issues have been previously raised by Athanasiadou et al. (2007).

\subsection{Variability of the plant material.}

The variation in bioactive compounds and biological activity (e.g., tannins) of plant materials is expected even among plants in the same geographic region in the same season (Alonso-Díaz et al., 2010b; Manolaraki, 2011). Many research teams are studying variability of nutraceutical materials in terms of varieties of plants, geographic locations, time of collection and modes of preservation (Manolaraki, 2011).

\section{Problems of identifying an in vivo AH effect of bioactive materials}

Testing biological activity under in vivo conditions may have one or more of several difficulties.

\subsection{The inherent features of the animals}

Premunition (Bowman et al., 2003) and innate resistance (Schallig, 2000) are well known mechanisms which can affect establishment or development of worm populations within hosts. Thus, the species of animals which are used for the in vivo studies may be an important source of bias if those two aspects are not considered. It is commonly advised to use parasite naïve animals which reduce, as much as possible, bias caused by the influence of premunition or innate resistance.

\subsection{Self cure phenomenon}

Materials should be administered for several days, or even weeks, to demonstrate the expected AH effect. Under such conditions established infections may become expelled from the animals due to the natural acquisition of an immune response (Balic et al., 2000). This could also compromise the experimental outcome.

\subsection{Improvement of the host's resilience and/or resistance}

The macronutrients in the nutraceutical may produce a positive indirect effect on the hosts to enhance their resistance or resilience (Hoste et al., 2011; Torres-Acosta et al., 2012). Thus, comparisons among animals fed the nutraceutical and the control group should consider including a supplement which provides the macronutrients without the bioactive compounds in the control group, or the experiment may have a wanted bias in favor of the group receiving the nutraceutic supplement.

\subsection{The quantity and quality of the material eaten}

As explained above, nutraceuticals should be consumed by the candidate host (Alonso-Díaz et al., 2010a). Thus, the material chosen should comply with the features of an edible material for the host species. As with other feedstuffs, physical characteristics of the nutraceuticals can influence host ingestion. The physical features (e.g., leaf size, presence of thorns) may impact intake (Ortega-Reyes and Provenza, 1993).

\subsection{Toxicity and/or negative effects}

It is a commonly held belief that the phytotherapeutic or nutraceutical options, as well as other "natural" products, are safer than synthetic drugs. As pointed out by Athanasiadou et al. (2007) this statement is incorrect because, in fact, many plant secondary metabolites (PSM) with AH effects may also have negative effects on the hosts. For example, tannins may affect diet digestibility (Méndez-Ortíz et al., 2012). However, according to the "trade-off" theory (Hutchings et al., 2003), 
animals will be willing to accept a certain degree of negative effect, such as a reduction in digestibility, when they ingest plant materials which provide them with positive effects, such as an AH effect.

\section{Results obtained with livestock species other than small ruminants}

A summary of results obtained using in vitro tests is in Table 1 and in vivo results are in Table 2 . Host species, parasite species, plant materials, techniques used and/or measured effects are described, as well as the main bioactive compound associated with the AH effect.

\subsection{Cattle}

Only a limited number of studies have evaluated use of forages or forage extracts against GIN of large ruminants. This could be the result of some researchers having only recently found evidence of the presence of resistant GIN strains on cattle farms, which stimulated a search for novel approaches against these parasites of cattle (Wolstenholme et al., 2004; Canul-Ku et al., 2012). It could also be due to experiments with cattle being more expensive than those with small ruminants or that adult cattle generally show stronger resistance against GIN than do small ruminants (Urquhart et al., 1996). However, the experience with small ruminants has been useful for cattle as many parasite life cycles in both hosts are similar (Bowman et al., 2003). Furthermore, both ruminant hosts share similar digestive physiology (Van Soest, 1994).

Effects of condensed tannin (CT) extracts from Onobrychis viciifolia, Lotus pedunculatus and L. corniculatus has been tested in vitro against Cooperia oncophora and Ostertagia ostertagi using LFIA and LEIA with good results. The role of CT was confirmed by adding polyvinylpolypyrrolidone (PVPP) (Novobilský et al., 2011). In addition to the CT effects on bovine GIN larvae and adults, hatching of bovine GIN eggs has been inhibited in vitro by aqueous extracts of Parkia biglobosa seeds or leaves (Soetan et al., 2011). Such extracts contained a mixture of alkaloids, cardenolides, saponins and tannins, but effects of each compound was not tested in an isolated manner. In addition, the saponin extract from Pennisetum glaucum inhibited egg hatching of bovine nematodes in vitro (Soetan and Lasisi, 2008).

Water extracts from Azadirachta indica or chopped Anana comosus leaves were examined in growing cattle resulting in egg count reductions of 67 and 95\% respectively. The latter was similar to the reduction for albendazole (98\%) in Akbar et al. (2003). Similarly, Nguni and crossbred cattle supplemented with Acacia karroo leaf meal as a source of CT at $1.5 \mathrm{~kg}$ daily for $60 \mathrm{~d}$ caused strongyle egg counts and mean total egg counts to be reduced. Additionally, lower Haemonchus sp and Oesophagostomum sp worm burdens were observed with A. karroo supplementation (Xhomfulana et al., 2009), although it was not possible to confirm the role of CT in these effects. A reduction of worm burdens also occurred in the group supplemented with sunflower meal in relation to non-supplemented animals (Xhomfulana et al., 2009). Thus, a possible indirect effect of supplementation could have occurred in a synergistic manner similar to those effects observed with sheep or goats (Torres-Acosta et al., 2012).

Although it can be argued that similar results could be obtained with GIN of cattle and small ruminants when using bioactive plant extracts or nutraceutical fodders, further studies may help to assess the influence of differences in rumen size, feed intake and digestion capacity of cattle in comparison with sheep and goats.

\subsection{Deer}

Relative to cattle, effects of bioactive fodders against GIN (Ostertagia-type and Trichostrongylus axei) as well as lungworms (Dictyocaulis eckerti) has been studied more frequently in red deer (Cervus elaphus).

The in vitro larval migration of the $\mathrm{L}_{1}$ stages of lungworm and $\mathrm{L}_{3}$ stages of GIN, according to LMIA, were inhibited when incubated with CT extracts from L. pedunculatus, L. corniculatus, Hedysarum coronarium and O. viciifolia. Additionally, the $\mathrm{L}_{3}$ of lungworm had a higher death rate compared to control (Molan et al., 2000). A crude extract of sesquiterpene lactones (SL) from Cichorium intybus had similar AH effects (Molan et al., 2003). Furthermore, adding CT to rumen fluid increased inhibition of migration of $\mathrm{L}_{1}$ lungworm larvae (measured with LMIA) and polyethylene glycol (PEG) removed this inhibition. However, no effect from CT occurred on egg hatching or development of GIN larvae (Schreurs et al., 2002).

Barry et al. (2002) reviewed main AH results against parasitic nematodes with plants containing secondary compounds such as CT and SL. Feeding Hedysarum coronarium reduced abomasal nematode establishment (Ostertagia-type and T. axei; Hoskin et al., 2000). Similar findings were reported for $H$. contortus in sheep fed O. viciifolia (Brunet et al., 2007) and goats fed Lysiloma latisilliquum (Brunet et al., 2008). Weaner deer grazing C. intybus required fewer AH treatments without depressing growth rates (Hoskin et al., 1999). Furthermore, grazing C. intybus also reduced the number of lungworm larvae developing to the $\mathrm{L}_{3}$ stage (Hoskin et al., 2000).

Similar to effects in sheep and goats, beneficial AH effects of CT-containing forages in deer have been attributed to factors such as direct inhibitory effects on parasite larvae. For example, both CT and SL have shown direct AH effects as measured by reduction of the motility of both lungworm and GIN larvae (Molan et al., 2000, 2003). Similar findings were obtained with tannin rich extracts against small ruminants GIN larvae (Alonso-Díaz et al., 2008). Indirect effects of CT have been measured by intake of tannin containing fodders which resulted in an increased rumen escape protein supply to the small intestine which could enhance amino acid absorption. The latter allows animals to obtain nutrients required to mount an effective immune response and to favor tissue repair and homeostasis (Barry et al., 2002). Similar effects have been suggested for 
Table 1

Summary of in vitro tests using plant extracts against helminths in different livestock species.

\begin{tabular}{|c|c|c|c|c|c|}
\hline \multirow[t]{2}{*}{ Plant } & \multicolumn{5}{|l|}{ In vitro test } \\
\hline & Extract or material & Host & Parasite & Test/effect & Reference \\
\hline $\begin{array}{l}\text { Onobrychis viciifolia } \\
\text { Lotus pedunculatus } \\
\text { Lotus corniculatus }\end{array}$ & Wa + Ace (leaves and stems) & Cattle & $\begin{array}{l}\text { Cooperia oncophora } \\
\text { Ostertagia ostertagi }\end{array}$ & $\begin{array}{l}\text { LFIA } \\
\text { LEA }\end{array}$ & Novobilský et al., 2011 \\
\hline Parkia biglobosa & Wa (seeds or leaves) & Cattle & GIN eggs & Egg hatching inhibition & Soetan et al., 2011 \\
\hline Pennisetum glaucum & Saponins & Cattle & GIN eggs & Egg hatching inhibition & Soetan and Lasisi, 2008 \\
\hline Cichorium intybus & Wa + Ace (leaves) & Deer & $\begin{array}{l}\text { Dictyocaulis eckerti } \mathrm{L}_{1} \text { larvae } \\
\text { and GIN } \mathrm{L}_{3} \text { larvae }\end{array}$ & LMIA & Molan et al., 2003 \\
\hline $\begin{array}{l}\text { L. pedunculatus } \\
\text { L. corniculatus } \\
\text { Hedysarum coronarium } \\
\text { Onobrychus viciifolia }\end{array}$ & Wa + Ace (Whole plant) & Deer & $\begin{array}{l}\text { Dictyocaulis eckerti } \mathrm{L}_{1} \text { larvae } \\
\text { and GIN } \mathrm{L}_{3} \text { larvae }\end{array}$ & $\begin{array}{l}\text { Lungworm larvae mortality } \\
\text { LMIA }\end{array}$ & Molan et al., 2000 \\
\hline C. intybus & Purified CT & Deer & Dictyocaulis eckerti & LMIA & Schreurs et al., 2002 \\
\hline Coleus blumei Benth & Leaf juices & Poultry & Raillietina spiralis & Death & Ridwan and Ayunita, 2007 \\
\hline C. blumei Benth & $\mathrm{He}, \mathrm{Ch}, \mathrm{Et}, \mathrm{Wa}$ (leaves) & Poultry & R. spiralis & Death & Ridwan et al., 2006 \\
\hline Crataeva nurvala & Et (root) & Poultry & Tapeworm & Paralysis and dead. & Kamath et al., 2011 \\
\hline Acacia oxyphylla & Me (stem) & Poultry & Raillietina echinobothrida & $\begin{array}{l}\text { Paralysis and destruction of } \\
\text { tegument }\end{array}$ & Dasgupta and Roy, 2010 \\
\hline $\begin{array}{l}\text { Tephrosia vogelli } \\
\text { Vernonia amygdalina }\end{array}$ & Wa (leaves) & Poultry & A. galli & LMIA & Siamba et al., 2007 \\
\hline $\begin{array}{l}\text { Polygonum hydropiper } \\
\text { Azadirachta indica } \\
\text { Carica papaya } \\
\text { Momordica charantia } \\
\text { Swietenia macrophylla }\end{array}$ & $\begin{array}{l}\text { Dust of leaves } \\
\text { Fresh juice } \\
\text { Wa, Et, Me (leaves) }\end{array}$ & Poultry & A. galli & Egg development inhibition & Islam et al., 2008 \\
\hline C. papaya & Latex solutions & Poultry & A. galli & Egg development inhibition & Purwati and $\mathrm{He}, 1991 \mathrm{~b}$ \\
\hline $\begin{array}{l}\text { Trichilia connaroides } \\
\text { Ajuga bracteosa } \\
\text { A. macrosperma } \\
\text { A. parviflora }\end{array}$ & $\begin{array}{l}\text { Me (seed and aerial parts) } \\
\text { Wa (root) }\end{array}$ & Poultry & A. galli & Paralysis & Agarwal et al., 2010 \\
\hline Jatropha curcas & Wa and Me (leaves) & Poultry & A. galli & $\begin{array}{l}\text { Paralysis } \\
\text { Death }\end{array}$ & Suharti et al., 2010 \\
\hline C. nurvala & Et (root) & Poultry & A. galli & Not specified & Kamath et al., 2011 \\
\hline A. oxyphylla & Et (stem) & Poultry & A. galli & Destruction of tegument & Lalchhandama et al., 2009 \\
\hline
\end{tabular}

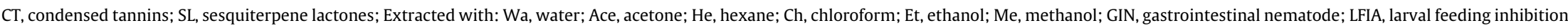
assay; LEA, larval exsheathment assay; LMIA, larvae migration inhibition assay. 
Table 2

Summary of in vivo trials assessing the AH effect of plant materials against helminths in different livestock species

\begin{tabular}{|c|c|c|c|c|c|}
\hline \multirow[t]{2}{*}{ Plant } & \multicolumn{5}{|l|}{ In vivo test } \\
\hline & Plant material & Host & Parasite & Effect & Reference \\
\hline Azadirachta indica & Wa (Leaves) & Cattle & GIN & Fecal egg reduction & Akbar et al., 2003 \\
\hline Anana comosus & Chopped leaves & Cattle & GIN & Fecal egg reduction & Akbar et al., 2003 \\
\hline Acacia karroo & Leaves (supplement) & Cattle & $\begin{array}{l}\text { Haemonchus sp. } \\
\text { Oesophagostomum sp. }\end{array}$ & $\begin{array}{l}\text { Fecal egg reduction } \\
\text { Reduction of worm } \\
\text { burden }\end{array}$ & Xhomfulana et al., 2009 \\
\hline Hedysarum coronarium & Whole plant (grazing) & Deer & $\begin{array}{l}\text { Ostertagia-type } \\
\text { Trichostrongylus axei } \\
\text { Lungworm larvae }\end{array}$ & $\begin{array}{l}\text { Reduction of abomasal } \\
\text { nematode } \\
\text { establishment } \\
\text { Reduction of lungworm } \\
\text { larval count in feces }\end{array}$ & Hoskin et al., 2000 \\
\hline Cichorium intybus & Whole plant (grazing) & Deer & GIN & Not specified & Hoskin et al., 1999 \\
\hline $\begin{array}{l}\text { Neocarya macrophylla } \\
\text { Celosia laxa } \\
\text { Zanthoxylum } \\
\text { zanthoxyloides }\end{array}$ & Et (leaves) & Rabbits & Ascaris sp. & $\begin{array}{l}\text { Higher body weight } \\
\text { Reduction of } \\
\text { eosinophyl counts }\end{array}$ & $\begin{array}{l}\text { Barnabas et al., } \\
\text { 2010-2011 }\end{array}$ \\
\hline Carica papaya & Papaya latex & Pigs & A. suum & $\begin{array}{l}\text { Reduction of worm } \\
\text { burden }\end{array}$ & Satrija et al., 1994 \\
\hline Quercus robur & Acorns (supplement) & Pigs & $\begin{array}{l}\text { A. suum } \\
\text { Oesophagostomum spp. } \\
\text { Strongyloides } \\
\text { Hyostrongylus spp. }\end{array}$ & Fecal egg reduction & Salajpal et al., 2004 \\
\hline Beta vulgaris & Soluble fibre & Pigs & $\begin{array}{l}\text { Oesophagostomum } \\
\text { dentatum }\end{array}$ & $\begin{array}{l}\text { Reduced establishment } \\
\text { and fecundity } \\
\text { Worm burden } \\
\text { reduction } \\
\text { Reduced FEC/worm } \\
\text { burden }\end{array}$ & $\begin{array}{l}\text { Petkevičius et al., } 2001 \\
\text { Petkevičius et al., } 2003\end{array}$ \\
\hline Coleus blumei Benth & He, Et, Wa (leaves) & Poultry & Raillietina spiralis & $\begin{array}{l}\text { Reduction of tapeworm } \\
\text { burden }\end{array}$ & Ridwan et al., 2006 \\
\hline $\begin{array}{l}\text { Tephrosia vogelli } \\
\text { Vernonia amygdalina }\end{array}$ & Wa (leaves) & Poultry & Ascaridia galli & Fecal egg reduction & Siamba et al., 2007 \\
\hline C. papaya & Papaya latex (fruit) & Poultry & A. galli & $\begin{array}{l}\text { Reduction of egg } \\
\text { infectivity } \\
\text { Reduction of worn } \\
\text { burden infection }\end{array}$ & $\begin{array}{l}\text { Purwati and } \mathrm{He}, 1991 \mathrm{a} \\
\text { Purwati and } \mathrm{He}, 1991 \mathrm{c}\end{array}$ \\
\hline C. papaya & Dry latex (Papain) & Poultry & A. galli & Fecal egg reduction & Adu et al., 2009 \\
\hline C. papaya & $\begin{array}{l}\text { Papaya seed powder and Wa } \\
\text { extract }\end{array}$ & Poultry & A. galli & Fecal egg reduction & Ameen et al., 2012. \\
\hline Jatropha curcas & Leave meal & Poultry & A. galli & Fecal egg reduction & Suharti et al., 2010 \\
\hline
\end{tabular}

Extracted with: Wa, water; He, hexane; Et, ethanol; GIN, gastrointestinal nematode. 
sheep and goats (Hoste et al., 2012; Torres-Acosta et al., 2012). Finally, plant morphology has been shown to be important as consumption of forage from taller plants may cause a reduction in ingestion of infective larvae (Barry et al., 2002) due to reduced forage infectivity of the apical plant parts. This has been also suggested for sheep grazing paddocks which combined grass and the browsing legume Leucaena leucocephala (Retama-Flores et al., 2012).

\subsection{Rabbits}

In many tropical countries, rabbits are a source of meat for human consumption. Smallholder farmers in many countries have traditionally used several plants to treat against their internal parasites, but little scientific validation has been collected. For example, Lans and Turner (2011) recently reported a plant species (Acer macrophillum) which, according to ethnoveterinary information, it is used for parasite control in rabbits. However no in vitro reports are in the scientific literature.

The ethanolic extracts of leaves of Zanthoxylum zanthoxyloides, Neocarya macrophylla and Celosia laxa were assessed against Ascaris sp infections in rabbits by Barnabas et al. (2010-2011). A reduced AH effect occurred with Z. zanthoxyloides while C. laxa had an AH effect followed by N. macrophylla. However, the authors related the higher AH effect to higher liveweight gain and lower eosinophil counts. No parasitological measurements, such as egg counts or worm counts, were reported. Given the ability of rabbits to eat many forages, there is a clear research opportunity to include bioactive materials, either as phytotherapeutics or nutraceuticals, to design and promote sustainable feeding systems.

\subsection{Pigs}

Possibly due to the industrial nature of commercial pig farms in many countries, GIN are not a major problem as pigs are kept inside under management protocols which reduce the chance of helminth infections. In addition, many pork production companies treat their animals with a commercial AH drug once or twice per year, even when they have no infection. Thus, GIN infections are mainly a problem for outdoor grazing production systems or smallholder production systems. It is evident that there is commercial interest in achieving control of GIN infections in outdoor pig production systems, especially amongst organic farmers (Thamsborg et al., 2010). However, in vivo research on use of plant materials for control of GIN has only produced few publications and no in vitro experiments were found in the scientific literature.

The AH effect of some phytogenic feed additives was evaluated as an infection of Ascaris suum in growing and finishing pigs using a mixture of Thymus vulgaris, Melissa officinalis and Echinacea purpurea, with or without Camellia sinensis. Additionally the individual plants C. papaya, Peumus boldus and Artemisia vulgaris. were also assessed. None of these materials were successful in reducing infection, although the herb mixture without $C$. sinensis and also $P$. boldus leaf slightly reduced the number of worms in the intestinal tract (Van Krimpen et al., 2010). However, other studies have shown that treatment with papaya latex at levels of 2,4 or $8 \mathrm{~g} / \mathrm{kg}$ liveweight reduced worm burdens of pigs naturally infected with $A$. suum by 40,80 and $100 \%$, respectively. However these studies also showed that a high dose of $C$. papaya latex may also produce a mild diarrhea or constipation in pigs (Satrija et al., 1994).

Use of Quercus robur (65 g tannin/kg DM) fed to Black Slavonian pigs raised in outdoor production systems with naturally acquired parasite infection resulted in a reduction of $96 \%$ in total GIN fecal egg count. The egg count reduction for $A$. suum was $97 \%$ while for the other GIN (i.e., Oesophagostomum sp, Strongyloides sp and Hyostrongylus sp) it was 94\% (Salajpal et al., 2004).

A promising avenue of research in control of parasitic nematodes of pigs has been with materials rich in fructans (inulin) such as Beta vulgaris. These easily fermentable carbohydrates can reduce egg output, worm burden and fecundity of Oesophagostomum dentatum (Petkevičius et al., 2001, 2003). Thamsborg et al. (2010) recently reviewed experiments performed in this area, including those investigating the possible mechanism of action: the production of short chain fatty acids during fermentation of carbohydrates in the large intestine (Petkevičius et al., 2004).

\subsection{Poultry}

Much like commercial pig production systems, the commercial poultry industry is highly specialized. However subsistence production systems in various parts of the world justifies the significant body of research evidence on AH activity of plant bioactive compounds in poultry. This has focused on tapeworms (Raillietina spiralis) and round worms (Ascaridia galli) in studies mainly in Asia and Africa where free range poultry remains an important rural activity. The World Association for the Advancement of Veterinary Parasitology guidelines for evaluating effectiveness of AH against parasite species affecting chickens and turkeys (Yazwinski et al., 2003) suggests only in vivo studies. However, several studies with plant materials have relied on in vitro and in vivo studies.

Leaf juices of Coleus blumei had strong AH activity against the chicken tapeworm Raillietina sp., probably because Coleus leaves contain flavonoids, steroids, tannins and saponins (Ridwan and Ayunita, 2007). Hexane, chloroform, ethanol and water extracts of Coleus leaves have also been tested. The highest activity has been with the chloroform extract, with a $\mathrm{EC}_{50}$ of $5 \mathrm{mg} / \mathrm{ml}$, followed by n-hexane $9 \mathrm{mg} / \mathrm{ml}$ and methanol extract $10.2 \mathrm{mg} / \mathrm{ml}$. The water extract had a weak AH activity of $106.2 \mathrm{mg} / \mathrm{ml}$. Chloroform proved to be a more efficient extractant of the bioactive compounds (Ridwan et al., 2006). Crataeva 
nurvala extract has also exhibited AH activity against tapeworms, but isolation of the active principles responsible for the activity was not completed (Kamath et al., 2011).

The crude methanolic extract of Acacia oxyphylla has been tested against Raillietina echinobothrida. Observation of the ultra structure on paralyzed worms revealed wide scale destruction of the parasite tegument with intense vacuolization of the syncytium and swellings of the basal lamina accompanied by deformities in the cell organelles. Phosphatase activity was decreased in tegumental enzymes. Alterations in the structural and functional integrity of the tegument seemed to compromise the permeability of the tegument under the influence of the plant extract (Dasgupta and Roy, 2010).

Extracts from Tephrosia vogelli and Vernonia amygdalina had AH activity against A. galli (using the LMIA). A migration inhibition of 75 and $64 \%$ occurred. The constituents of these plants included rotenoids, SL, glycosides, anthracenes and tannins (Siamba et al., 2007). Islam et al. (2008) reported results with Polygonum hydropiper, A. indica, C. papaya, Momordica charantia and Swietenia macrophylla as fresh juice, extracts (i.e., aqueous, ethanol, methanol extracts) and leaves as a dry powder. Extracts of $C$. papaya had the highest AH efficacy as tested by inhibition of nematode egg development. Amongst the selected plants, fresh juice of $P$. hydropiper leaves had the highest effectiveness and the $P$. hydropiper leaves was the most effective against $A$. galli. Consequently, these authors proposed that using $P$. hydropiper leaves added to the litter may cause inhibition of development of $A$. galli eggs. In a similar fashion, they proposed use fresh juice and the extract of $P$. hydropiper, $A$. indica and C. papaya to impregnate the bedding, which can be used after it is sun-dried. Also, the latex of $C$. papaya tree has proved effective against development of infective eggs (Purwati and He, 1991b).

The mode of action of the bioactive compounds in methanol, chloroform, acetone and aqueous extracts of Trichilia connaroides, Ajuga bracteosa, A. macrosperma and A. parviflora was evaluated by measuring the frequency and amplitude of spontaneous muscular contractions of adult $A$. galli. Inhibition in amplitude and frequency of the contractile activity in a dose dependent manner occurred for methanol extracts of seeds, pericarps, the aqueous extract of roots of T. connaroides, and methanol extracts of $A$. parviflora and $A$. macrosperma roots, as well as A. bracteosa aerial parts. These observations indicate the paralyzing effect of the extracts on A. galli. There was no inhibition of the contractile activity when using chloroform extracts of seeds, acetone extracts of leaves of $T$. connaroides or the methanol extract of A. bracteosa roots (Agarwal et al., 2010). The authors concluded that extracts demonstrated a paralyzing effect caused by progressive reduction in spontaneous muscular activity which may be associated with an inhibitory effect on the neuromuscular system of $A$. galli. The effect of T. connaroides extracts was attributed to the presence of polyphenols. The activity found in the extracts of the genus Ajuga (i.e., A. bracteosa, A. macrosperma, A. parviflora) was attributed to the presence of clerodane and neo-clerodane diterpenoids (Agarwal et al., 2010). However, there was no confirmation of the activity of those compounds or any other compounds. Studies with Jatropha curcas leaf water extract or the methanolic extract (rich in triterpenoids and steroids) had a paralyzing effect which was higher with the water extract. Meanwhile, the killing percentage was higher with the methanol extract (Suharti et al., 2010). Finally, the ethanol extract from roots of Crataeva nurvala exhibited AH activity against A. galli (Kamath et al., 2011).

Similar to findings with chicken tapeworms (Dasgupta and Roy, 2010), when the ethanol extract of Acacia oxyphylla Graham ex Bentham stem bark was tested, scanning electron microscopy indicated severe structural alterations on the fine topography of A. galli. Severe shrinkage of the cuticle, loosening and collapse of the lips, and extensive irregular wrinkles all over the body surface were very distinct on the plant extract-treated nematodes. Moreover, high magnification of the cuticle revealed formation of a number of small swellings or blebs, which apparently marked the initiation of disintegration of the entire cuticle (Lalchhandama et al., 2009).

Only one report is in the literature regarding in vivo assessment of bioactive compounds of Raillietina sp. against chicken tapeworm. Despite promising in vitro results when assessed in vivo with chickens, the chloroform extract of $C$. blumei ( $25 \mathrm{mg} / \mathrm{kg} \mathrm{BW}$ ) did not reduce the number of tapeworms (Ridwan et al., 2006).

More research has been completed regarding in vivo assessment of AH effects of plant bioactive compounds against $A$. galli. The AH activity of C. papaya has been reported against adult worms (Purwati and He, 1991a,c; Singh and Nagaich, 1999; Satrija et al., 2001; Adu et al., 2009; Ameen et al., 2012). Purwati and He (1991a,c) assessed efficacy of C. papaya latex as an oral administration of a $20 \%$ water solution in laying hens, with a patent experimental infection and found $100 \%$ efficacy with a single treatment of $1120 \mathrm{mg} / \mathrm{bird} / \mathrm{d}$. Meanwhile, Adu et al. (2009) found that $1200 \mathrm{mg}$ extract/bird/d (i.e., papain) caused a $78 \%$ reduction of EPG. Finally, effects of papaya seed powder at $300 \mathrm{mg} / \mathrm{bird} / \mathrm{d}$ and the water extract of the seed powder at $1 \mathrm{ml} / 10 \mathrm{ml}$ of water administered at $500 \mathrm{mg} / \mathrm{bird} / \mathrm{d}$ showed $100 \%$ fecal egg reduction two wks after the second dosage in naturally infected layers (Ameen et al., 2012).

Extracts from $T$. vogelli and $V$. amygdalina caused a fecal egg count reduction of 77 and $77 \%$, respectively, and reduced total worm counts at necropsy (Siamba et al., 2007). Additionally, J. curcas leaf meal caused a reduction in fecal worm egg counts (Suharti et al., 2010).

\section{Conclusions}

There is a clear AH potential amongst several plant materials against the most common parasites of small ruminants, cattle, deer, pigs, rabbits and poultry. The bioactive compounds contained in phytotherapeutics and nutraceuticals tested to date vary. Further research is needed to understand modes of action under in vivo conditions before commercial adoption. While applicability of bioactive materials should be studied in various production systems with various farm animal species, they may become important in the design of sustainable helminth management strategies. 


\section{Acknowledgements}

The authors acknowledge the funding by PCP-CONACYT (no. 04/09), CONACYT Ciencia Básica (no. 106146).

\section{References}

Adu, O.A., Akingboy, K.A., Akinfemi, A., 2009. Potency of pawpaw (Carica papaya) latex as an anthelmintic in poultry production. Bot. Res. Int. 2, $139-142$.

Agarwal, G., Pant, A.K., Hore, S.K., 2010. In vitro evaluation of anthelmintic efficacy of Trichilia and Ajuga species on Ascaridia galli. Hygeia J. Drugs Med. 2 , 45-53.

Akbar, M.A., Ahmed, T.U., Mondal, M.H., 2003. Study on the efficacy of different herbal plants against nematode infection in cattle. Trop. Subtrop. Agroecosyst. 3, 515-518.

Ali, Z.A., 1999. Folk veterinary medicine in Moradabad district (Uttar Pradesh), India. Fitoterapia 70, 340-347.

Alonso-Díaz, M.A., Torres-Acosta, J.F.J., Sandoval-Castro, C.A., Hoste, H., Aguilar-Caballero, A.J., 2008. In vitro larval migration and kinetics of exsheathment of Haemonchus contortus larvae exposed to four tropical tanniniferous plant extracts. Vet. Parasitol. 153, 313-319.

Alonso-Díaz, M.A., Torres-Acosta, J.F.J., Sandoval-Castro, C.A., Hoste, H., 2010a. Tannins in tropical tree fodders fed to small ruminants: a friendly foe? Small Ruminant Res. 89, 164-173.

Alonso-Díaz, M.A., Torres-Acosta, J.F.J., Sandoval-Castro, C.A., Capetillo-Leal, C.M., 2010b. Polyphenolic compounds of nutraceutical trees and the variability of their biological activity measured by two methods. Trop. Subtrop. Agroecosyst. 12, 649-656.

Alonso-Díaz, M.A., Torres-Acosta, J.F.J., Sandoval-Castro, C.A., Hoste, H., 2011. Comparing the sensitivity of two in vitro assays to evaluate the anthelmintic activity of tropical tannin rich plant extracts against Haemonchus contortus. Vet. Parasitol. 181, 360-364.

Ameen, S.A., Adedeji, O.S., Ojedapo, L.O., Salihu, T., Fakorede, O.L., 2012. Anthelmintic efficacy of paw paw (Carica papaya) seeds in commercial layers. Afr. J. Biotechnol. 11, 126-130.

Andlauer, W., Furst, P., 2002. Nutraceuticals: a piece of history, present status and outlook. Food Res. Int. 35, 171-176.

Athanasiadou, S., Githiori, J., Kyriazakis, I., 2007. Medicinal plants for helminth parasite control: facts and fiction. Animal 1, $1392-1400$.

Balic, A., Bowles, V.M., Meeusen, E.N.T., 2000. The immunobiology of gastrointestinal nematode infections in ruminants. Adv. Parasitol. 45, 182-229.

Barnabas, B.B., Mann, A., Ogunrinola, T.S., Anyanwu, P.E., 2010-2011. Screening for anthelmintic activities from extracts of Zanthoxylum zanthoxyloides Neocarya macrophylla and Celosia laxa against Ascaris infection in rabbits. Int. J. Appl. Res. Nat. Prod. 3, 1-4.

Barry, T.N., Hoskin, S.O., Wilson, P.R., 2002. Novel forages for growth and health in farmed deer. N. Z. Vet. J. 50, $244-251$.

Bowman, D.D., Lynn, R.C., Eberhard, M.L., 2003. Georgis' Parasitology for Veterinarians. Sauders, Elsevier Science, St. Louis, MO, USA.

Brunet, S., Aufrere, J., El Babili, F., Fouraste, I., Hoste, H., 2007. The kinetics of exsheathment of infective nematode larvae is disturbed in presence of tannin rich plant (sainfoin) both in vitro and in vivo. Parasitology 134, 1253-1262.

Brunet, S., Montellano, C.M.-O., Torres-Acosta, d., Sandoval-Castro, J.F.J., Aguilar-Caballero, C.A., Capetillo-Leal, A.J., Hoste, C.H., 2008. Effect of the consumption of Lysiloma latisiliquum on the larval establishment of gastrointestinal nematodes in goats. Vet. Parasitol. 157, 81-88.

Canul-Ku, H.L., Rodriguez-Vivas, R.I., Torres-Acosta, J.F.J., Aguilar-Caballero, A.J., Pérez-Cogollo, L.C., Ojeda-Chi, M.M., 2012. Prevalence of cattle herds with ivermectin resistant nematodes in the hot sub-humid tropics of Mexico. Vet. Parasitol. 183, 292-298.

Coles, G.C., Jackson, F., Pomroy, W.E., Prichard, R.K., von Samson-Himmelstjerna, G., Silvestre, A., Taylor, M.A., Vercruysse, J., 2006. The detection of anthelmintic resistance in nematodes of veterinary importance. Vet. Parasitol. 136, 167-185.

Dasgupta, S., Roy, B., 2010. Antiparasitic activity of methanolic extract of Acacia oxyphylla (Leguminosae) against Raillietina echinobothrida. J. Parasitic Dis. $34,14-19$.

Githiori, J.B., Höglund, J., Waller, P., 2005. Ethnoveterinary plant preparations as livestock dewormers: practices, popular beliefs, pitfalls and prospects for the future. Anim. Health Res. Rev. 6, 91-103.

Githiori, J.B., Athanasiadou, S., Thamsborg, S.M., 2006. Use of plants in novel approaches for control of gastroinstestinal helminths in livestock with emphasis on small ruminants. Vet. Parasitol. 139, 308-320.

Hoskin, S.O., Barry, T.N., Wilson, P.R., Charleston, W.A.G., Hodgson, J., 1999. Effects of reducing anthelmintic input upon growth and faecal egg and larval counts in young farmed deer grazing chicory (Cichorium intybus) and perennial ryegrass (Lolium perenne)/white clover (Trifolium repens) pasture. J. Agric. Sci. 132, 335-345.

Hoskin, S.O., Wilson, P.R., Barry, T.N., Charleston, W.A.G., Waghorn, G.C., 2000. Effect of forage legumes containing condensed tannins on lungworm (Dictyocaulus sp.) and gastrointestinal parasitism in young red deer (Cervus elaphus). Res. Vet. Sci. 68, 223-230.

Hoste, H., Torres-Acosta, J.F., Paolini, V., Aguilar-Caballero, A., Etter, E., Lefrileux, Y., Chartier, C., Broqua, C., 2005. Interactions between nutrition and gastrointestinal infections with parasitic nematodes in goats. Small Ruminant Res. 60, 141-151.

Hoste, H., Torres-Acosta, J.F., Alonso-Díaz, M.A., Brunet, S., Sandoval-Castro, C., Adote, S.H., 2008. Identification and validation of bioactive plants for the control of gastrointestinal nematodes in small ruminants. Trop. Biomed. 25, 56-71.

Hoste, H., Manolaraki, F., Brunet, S., Arroyo-Lopez, C., Martinez-Ortiz-de-Montellano, C., Sotiraki, S., Torres-Acosta, F., 2011. The anthelmintic properties of tannin-rich legume forages: from knowledge to exploitation in farm conditions. Challenging strategies to promote the sheep and goat sector in the current global context. In: Ranilla, M.J., Carro, M.D., Ben Salem, H., Morand-Fehr, P. (Eds.), Options Méditerranéennes. Series A. Num. 99. , pp. 295-310.

Hoste, H., Martinez-Ortiz-De-Montellano, C., Manolaraki, F., Brunet, S., Ojeda-Robertos, N., Fourquaux, I., Torres-Acosta, J.F.J., Sandoval-Castro, C.A., 2012. Direct and indirect effects of bioactive tannin rich tropical and temperate legumes against nematode infections. Vet. Parasitol. 186, 18-27.

Hutchings, M.R., Judge, J., Gordon, I.J., Athanasiadou, S., Kyriazakis, I., 2003. Use of trade-off theory to advance understanding of herbivore-parasite interactions. Mamm. Rev. 36, 1-16.

Islam, K.R., Farjana, T., Begum, N., Mondal, M.M.H., 2008. In vitro efficacy of some indigenous plants on the inhibition of development of eggs of Ascaridia galli (Digenia: nematoda). Bangladesh J. Vet. Med. 6, 159-167.

Jackson, F., Hoste, H., 2010. In vitro methods for the primary screening of plant products for direct activity against ruminant gastrointestinal nematodes. In: Vercoe, P.E., Schlink, A.C., Makkar, H.P.S. (Eds.), In Vitro Screening of Plant Resources for Extra-nutritional Attributes in Ruminants: Nuclear and Related Methodologies. Springer, London, UK, pp. 24-45.

Kamath, R., Shetty, D., Bhat, P., Shabaraya, A.R., Hegde, K., 2011. Evaluation of antibacterial and anthelmintic activity of root extract of Crataeva nurvala. Pharmacology (Online) 1, 617-622.

Lalchhandama, K., Roy, B., Dutta, B.K., 2009. Anthelmintic activity of Acacia oxyphylla stem bark against Ascaridia galli. Pharm. Biol. 47, 578-583.

Lans, C., Turner, N., 2011. Organic parasite control for poultry and rabbits in British Columbia, Canada. J. Ethnobiol. Ethnomed. 7, 21.

Manolaraki, F., 2011. Propriétés Anthelminthiques du Sainfoin (Onobrychis viciifoliae): Analyse des Facteurs de Variations et du rôle des Composés Phénoliques Impliqués. Soutenue le 21 Janvier 2011. INP, Toulouse, France.

Matin, A., Khan, M.A., Ashraf, M., Qureshi, R.A., 2001. Traditional use of herbs, shrubs and trees of Shogran valley Mansehra, Pakistan. Pak. J. Biol. Sci. 4, 1101-1107.

Méndez-Ortíz, F.A., Sandoval-Castro, C.A., Torres-Acosta, J.F.J., 2012. Short term consumption of Havardia albicans tannin rich fodder: Effect on feed intake, diet digestibility and excretion of Haemonchus contortus eggs in sheep. Anim. Feed Sci. Technol. 176, 185-191.

Molan, A.L., Duncan, A.J., Barry, T.N., McNabb, W.C., 2003. Effects of condensed tannins and crude sesquiterpene lactones extracted from chicory on the motility of larvae of deer lungworm and gastrointestinal nematodes. Parasitol. Int. 52, 209-218.

Molan, A.L., Hoskin, S.O., Barry, T.N., McNab, W.C., 2000. The effect of condensed tannins extracted from four forages on deer lungworm and gastrointestinal nematode viability. Vet. Rec. 147, 44-48. 
Mueller-Harvey, I., 2006. Unravelling the conundrum of tannins in animal nutrition and health. J. Sci. Food Agric. 86, $2010-2037$.

Novobilský, A., Mueller-Harvey, I., Thamsborg, S.M., 2011. Condensed tannins act against cattle nematodes. Vet. Parasitol. $182,213-220$.

Ortega-Reyes, L., Provenza, F.D., 1993. Experience with blackbrush affects ingestion of shrub live oak by goats. J. Anim. Sci. 71, $380-383$.

Petkevičius, S., Bach Knudsen, K.E., Nansen, P., Murrell, K.D., 2001. The effect of dietary carbohydrates with different digestibility on the populations of Oesophagostomum dentatum in the intestinal tract of pigs. Parasitology 123, 315-324.

Petkevičius, S., Bach Knudsen, K.E., Murrell, K.D., Wachmann, H., 2003. The effect of inulin and sugar beet fibre on Oesophagostomum dentatum infection in pigs. Parasitology 127, 61-68.

Petkevičius, S., Murrell, K.D., Bach Knudsen, K.E., Jørgensen, H., Roepstorff, A., Laue, A., Wachmann, H., 2004. Effects of short-chain fatty acids and lactic acids on survival of Oesophagostomum dentatum in pigs. Vet. Parasitol. 122, 293-301.

Purwati, E., He, S., 1991a. Pengaruh getah pepaya (Carica papaya) terhadap infektivitas telur Ascaridia galli pada ayam [effect of papaya latex (Carica papaya) against Ascaridia galli egg infectivity in chickens]. Hemera Zoa 74, 1-5.

Purwati, E., He, S., 1991b. Pengaruh getah pepaya (Carica papaya) terhadap Ascaridia galli dewasa in vitro. Effect of papaya latex (Carica papaya) against Ascaridia galli grown in vitro. Hemera Zoa 74, 6-10.

Purwati, E., He, S., 1991c. A potential role of papaya latex as an anthelmintic against patent Ascaridia galli infection in chicken. Hemera Zoa 74, 11-20.

Retama-Flores, C., Torres-Acosta, J.F.J., Sandoval-Castro, C.A., Aguilar-Caballero, A.J., Cámara-Sarmiento, R., Canul-Ku, H.L., 2012. Maize supplementation of pelibuey sheep in a silvopastoral system: fodder selection, nutrient intake and resilience against gastrointestinal nematodes. Animal 6, $145-153$.

Ridwan, Y., Ayunita, Y.Q., 2007. Phytochemical and anthelmintic activity against chicken tapeworm of painted nettle (Coleus blumei benth) varieties in vitro. J. Prot. 14, 17-20.

Ridwan, Y., Darusman, L.K., Satrija, F., Handaryani, E., 2006. Chemical compound of painted nettle (Coleus blumei Benth) leaves extracts and their anthelmintic activity against chicken tapeworm. Jurnal Ilmu Pertanian Indonesia 11 (2), 1-6.

Rochfort, S., Parker, A.J., Dunshea, F.R., 2008. Plant bioactives for ruminant health and productivity. Phytochemistry 69, $299-322$.

Salajpal, K., Karolyi, D., Beck, R., Kiš, G., Vicković, I., Đikić, M., Kovačić, D., 2004. Effect of acorn (Quercus robur) intake on faecal egg count in outdoor reared black slavonian pig. Acta Agric. Slovenica (supplement) 1, 173-178.

Satrija, F., Nansen, P., Bjorn, H., Murtini, S., He, S., 1994. Effect of papaya latex against Ascaris suum in naturally infected pigs. J. Helminthol. 68, $343-346$.

Satrija, F., Retnani, E.B., Ridwan, Y., Tiuria, R., 2001. Potential use of herbal anthelmintics as alternative antiparasitic drugs for small holder farms in developing countries. In: Livestestock Community and Environment. Proceedings of the 10th Conference of the Association of Institutions for Tropical Veterinary Medicine, Copenhagen, Denmark.

Schallig, H.D.F.H., 2000. Immunological responses of sheep to Haemonchus contortus. Parasitology 120, S63-S72.

Schreurs, N.M., Lopez-Villalobos, N., Barry, T.N., Molan, A.L., McNabb, W.C., 2002. Effects of grazing undrenched weaner deer on chicory or perennial ryegrass/white clover pasture on the viability of gastrointestinal nematodes and lungworms. Vet. Rec. 151, 348-353.

Siamba, D.N., Okitoi, L.O., Watai, M.K., Wachira, A.M., Lukibisi, F.B., Mukisira, E.A., 2007. Efficacy of Tephrosia vogelli and Vernonia amygdalina as anthelmintics against Ascaridia galli in indigenous chicken. Livest. Res. Rural Dev. 19, 176.

Singh, K., Nagaich, S., 1999. Efficacy of aqueous seed extract of Carica papaya against common poultry worms Ascaridia galli and Heterakis gallinarum. J. Parasitic Dis. 23, 113-116.

Smidt, N.W., Brimer, L., 2005. The use of herbs in pastures: an interview survey among bio-dynamic and organic farmers with dairy cattle. Agric. Hum. Values 22, 355-363.

Soetan, K.O., Lasisi, O.T., 2008. Studies on the anthelmintic activities of saponins from Pearl millet (Pennisetum glaucum). Trop. Vet. $26,14-19$.

Soetan, K.O., Lasisi, O.T., Agboluaje, A.K., 2011. Comparative assessment of in vitro anthelmintic effects of the aqueous extracts of the seeds and leaves of the African locust bean (Parkia biglobosa) on bovine nematode eggs. J. Cell Anim. Biol. 5, 109-112.

Stepek, G., Behnke, J.M., Buttle, D.J., Duce, I.R., 2004. Natural plant cysteine proteinases as anthelmintics. Trends Parasitol. 7, $322-327$.

Sudarsanam, G., Reddy, M.B., Nagaraju, N., Alkofahi, A., Al-Khalil, S., 1995. Veterinary crude drugs in Rayalaseema, Andhra Pradesh, India. Pharm. Biol. 33, $52-60$.

Suharti, S., Wiryawana, K.G., Tiuriab, R., Ridwanb, Y., Fitrianaa, S., Sumarnia, N., 2010. Effectiveness of Jatropha curcass Linn leaves as an anthelmintic for Ascaridia galli and its effect on native chicken performance. Media Peternakan 33, 108-114.

Thamsborg, S.M., Roepstorff, A., Nejsum, P., Mejer, H., 2010. Alternative approaches to control of parasites in livestock: Nordic and Baltic perspectives. Acta Vet. Scand. 52 (Suppl 1), S27.

Torres-Acosta, J.F.J., Sandoval-Castro, C.A., Hoste, H., Aguilar Caballero, A.J., Cámara-Sarmiento, R., Alonso-Diaz, M.A., 2012. Nutritional manipulation of sheep and goats for the control of gastrointestinal nematodes under hot humid and subhumid tropical conditions. Small Ruminant Res. 103, 28-40.

Urquhart, G.M., Armour, J., Duncan, J.L., Dunn, A.M., Jennings, F.W., 1996. Veterinary Parasitology, 2nd edition. Blackwell Science Ltd., Oxford, UK.

Van Krimpen, M.M., Binnendijk, G.P., Borgsteede, F.H.M., Gaasenbeek, C.P.H., 2010. Anthelmintic effects of phytogenic feed additives in Ascaris suum inoculated pigs. Vet. Parasitol. 168, 269-277.

Van Soest, P.J., 1994. Nutritional Ecology of the Ruminant, 2nd edition. Cornell. University Press, Ithaca, NY, USA.

Waller, P.J., Bernes, G., Thamsborg, S.M., Sukura, A., Richter, S.H., Ingebrigtsen, K., Höglund, J., 2001. Plants as de-worming agents of livestock in the Nordic countries: historical perspective, popular beliefs and prospects for the future. Acta Vet. Scand. 42, 31-44.

Wolstenholme, A.J., Fairweather, I., Prichard, R., von Samson-Himmelstjerna, G., Sangster, N.C., 2004. Drug resistance in veterinary helminthes. Trends Parasitol. 20, 469-476.

Wood, I.B., Amaral, N.K., Bairden, K., Duncan, J.L., Kassai, T., Malone Jr., J.B., Pankavich, J.A., Reinecke, R.K., Slocombe, O., Taylor, S.M., Vercruysse, J., 1995. World Association for the Advancement of Veterinary Parasitology (W.A.A.V.P.) second edition of guidelines for evaluating the efficacy of anthelmintics in ruminants (bovine, ovine, caprine). Vet. Parasitol. 58, 181-213.

Xhomfulana, V., Mapiye, C., Chimonyo, M., Marufu, M.C., 2009. Supplements containing Acacia karroo foliage reduce nematode burdens in Nguni and crossbred cattle. Anim. Prod. Sci. 49, 646-653.

Yazwinski, T.A., Chapman, H.D., Davis, R.B., Letonja, T., Pote, L., Maes, L., Vercruysse, J., Jacobs, D.E., 2003. World Association for the Advancement of Veterinary Parasitology (WAAVP) guidelines for evaluating the effectiveness of anthelmintics in chickens and turkeys. Vet. Parasitol. 116, $159-173$. 